\title{
Influence of Study Habits on Academic Performance of International College Students in Shanghai
}

\author{
Miguel A. Cerna ${ }^{1} \&$ Ksenia Pavliushchenko (research assistant) ${ }^{1}$ \\ ${ }^{1}$ Center of International Programs, Donghua University, China \\ Correspondence: Miguel A. Cerna, Center of International Programs, Donghua University, Shanghai, China. Tel: \\ 86-216-237-3362. E-mail: Miguel.cerna@icloud.com
}

Received: May 11, 2015

Accepted: June 9, 2015

Online Published: July 21, 2015

doi:10.5539/hes.v5n4p42

URL: http://dx.doi.org/10.5539/hes.v5n4p42

\begin{abstract}
The present study estimates the global validity of existing constructs and serves as the basis for the development of the Self-Reported Study Habits for International Students (SR-SHI) used to identify at-risk students in international programs. One-year classroom observations, recollection of study habits though interviews with high performing students show that they are mainly from low-context and individualistic countries while most low performing students come from high-context and collectivistic countries.

Among other aspects, high performing students give opinions based on reading material and class content, use the expression "I think", ask questions in class, are on time, ask for feedback regarding assignments, take notes in class and while studying, look for the professor after class, seat at the front of the classroom and attend every class, study in silence and alone at regular times along the whole semester, read the material about two weeks before the exam, review notes before the exam, talk about the content with other students. On the other hand, low performing students remind quite the whole semester, miss at least three classes per semester, are normally late, sit at the back of the classroom, don't take notes in class and never look for the professor after class-hours. It seems that specific training programs at the start and during the semester as well as training on cultural intelligence were identified are necessary.
\end{abstract}

Keywords: academic performance, high/low-context countries, high-performing students, low-context country, multicultural classroom, study habits

\section{Statement of Problem}

Perhaps the greatest challenge of faculty teaching in multicultural classrooms in college is to devise teaching methodologies that help all students to learn and understand the subjects under discussion. This researcher sustains that all things being equal, what remains different in a multicultural classroom is the cultural background (and the implied habits) of students and teachers. Class observations and interview with high-performing students showed that most high and low performing students have some habits in common. Hence, it is considered important to know what habits college students have and, in case of low-performing students, which of those habits need to be changed in order to improve performance. The importance of improving habits lays in their relationship with attitudes, which are deemed important for achieving high academic performance.

A great deal of research provides evidence that study habits and study attitudes are both significant variables, which determine the academic performance of students. Yet, in spite of the perceived importance of study habits and study attitudes to academic achievement, it seems that education institution still pay little attention to understanding these factors (Baquiran, 2011).

Classroom observations show that under the same conditions, namely same professor, same subject, same teaching system, same administration, same enrollment criteria, same time of the day for an specific course and same education level, some students perform well while others do not. The question arises as to what are the aspects that influence this difference in performance, and what is the best way to arrange the study process of multicultural groups of college students, so that all learn and preform accordingly with schools' expectations. 


\section{Relevance}

To the knowledge of the investigator, this is the first study regarding the effect of study habits on academic performance conducted with international students in Shanghai. Most studies up-to-date have been conducted in mono-cultural classrooms, where students and professors are from the same country, mainly in the west, with students in secondary and primary schools. Several of those studies are archival reviews of previous research. None of the previous studies, relevant to this investigation, found in the existing literature addresses the issue of the effect of study habits on academic performance from the perspective of multicultural classrooms in fully international programs (See subheading 3.2 below). Besides, international evidence regarding academic performance is becoming more and more important for China in general and Shanghai in particular, since more students from a wider pool of countries are entering international programs in Shanghai.

The of the first fully English taught bachelor program for non-Chinese student in China was founded in 2009 at the Center of International Programs (CIP) of Donghua University, Yan'an Campus, where this investigation was conducted. At the moment (January, 2015) there are twenty similar programs in other mayor cities such as Beijing, Nanjing, Ningbo, Hangzhou, Guangzhou, Qingdao, Wuxi, Nanchang, Jinan and Zhejiang. However, CIP remains unique in regard to the international community of students and professors. This is evidence of the increasing international focus on China. Hence, the researcher predicts that more college international programs will be established in China.

Education institutions as well as students and society may benefit from the results of this investigation. Institutions may benefit with data that may allow them to evaluate their current admission policies and counseling programs, teachers may find this research useful to design more suitable classroom practices and students may have a clearer idea of the challenges they may face based on their current study habits and hence prepare better to perform well during the whole study period, and finally, society may benefit by receiving young professionals that are better prepared for the day-to-day challenges on global working environments.

\section{Theoretical Background}

\subsection{Definitions}

\subsubsection{Study Habits}

Study habits are mainly external factors that facilitate the study process such as sound study routines that include how often a student engage in studying sessions, review the material, self-evaluate, rehears explaining the material, and studying in a conducive environment (Credé, 2008).

\subsubsection{Study Skills}

Study skills refer to the student's knowledge of appropriate study strategies and methods and the ability to manage time and other resources to meet the demands of the academic tasks.

\subsubsection{Multicultural Classroom}

Within the framework of this investigation, multicultural classroom refers to classroom where students and professors are from different cultural backgrounds.

\subsubsection{International Bachelor Program}

Within the framework of this investigation, an international bachelor program refers to that where students come mainly from countries other than the one where the program takes place, which may or may not accept local students, and where all the courses are taught in English.

\subsubsection{High Performing Students}

Different education institutions form different standards to measure students' performance. For the purpose of this investigation, high performing students are define as those who, based on standards of the institution where this research took place, reached grades of 90 or above in $100 \%$ of the required courses and in at least $80 \%$ of elective courses.

\subsection{Chronology of the Study of Study Habits}

Previous proposed constructs to explain low academic performance include study skills (e.g., Aaron, 1999), study habits (e.g., Murray, 2003), study attitudes (e.g., Zimmerman, 1977), study motivation (e.g., Melancon, 2002), meta-cognitive skills (e.g., Zeegers, 2001), study anxiety (e.g., Miller, 1972), procrastination (e.g. Pychyl, 2000) and depth of processing (e.g., Hall, 2001). These are individual difference factors that have been grouped into intellective (cognitive) and non-intellective (non-cognitive) factors (Credé, 2008). 
Previous to this investigation, the most resent research on study habits and attitudes of college students was conducted by Ivan Montes in Spain (2012). Montes tracked changes in study habits in college students from the time they entered the program to the time of graduation (5 years). Previously to Montes, Darwing D. Yu (2011) conducted a study on the topic of study habits with sophomore students whose major was accounting. Luisa Baquiran L. A. (2011) also in the Philippines, conducted a similar study with freshman students from different majors. Greene, Marti and McClenney (2008) conducted a cross-cultural study focused on effort of African American and Hispanic college students. Gilbert Wrenn C. C. (1933) published one of the first study habits inventories in the United States (Brown, 1955). Wrenn C. C.'s inventory was originally designed for men, but was modified later for women (Wrenn, 1941). He suggested that study habits might correspond to academic success if ability was controlled (Thompson, 1976). All studies conducted after Wrenn C. C. and Brown W. F. (1972) utilized slight modifications of the existing SSHA developed by Wrenn, C. C. and later modified by Brown, W. F.. They all agreed that study habits significantly influence academic performance.

Noel Entwistle (1960) reviewed existing literature and made evaluations of 22 study skills courses. He concluded that a study skills course will usually be followed by improvement, a course will be most beneficial for students desiring to take it, students wishing to take a study skills course but prevented from doing so, and therefore presumably of comparable motivation to those enrolled, fail to show significant improvement, and that any gains noted will not necessarily be related to either the content or the duration of the course.

The Brown, W. F. Holtzman Survey of Study Habits Attitudes (SSHA) Inventory is generally acknowledged as one of the best study habit attitude inventories in the United States. They introduced a questionnaire concerning study habits and attitudes in 1953; the original inventory had 75 items. There have been several revisions (the most recent in 1967), and the length of the inventory is now 100 items. This inventory, which is widely used as a research tool, has four scales: 1) Work methods - use of effective study procedures, skill and efficiency in doing academic assignments. 2) Delay avoidance - promptness in completing assignments and ability to resist distractions. 3) Teacher approval-feelings and opinions about teachers, their classroom behavior, and their methods. 4) Educational acceptance - approval of educational objectives, practices and requirements (Thompson, 1976).

McFadden and Dart (1992), in their study of time management skills of undergraduate business students, found that study habits and total time spent studying do affect grades. On the other hand, Nonis and Hudson (2006) found that the amount of time spent studying, measured during the ninth week of a 15-week semester, has not direct influence on academic performance, although it interacted with academic ability to affect academic performance.

Lavin (1965) conducted an extensive study regarding the prediction of academic performance (300 studies reviewed and analyzed), and found that ability accounts for 35 to 45 percent of the variation in grades. No other single factor accounts for this much variation, yet more than half remains unexplained. Among those yet-to-explain factors are study habits.

Studies conducted after the 70's make use of this construct to evaluate what habits of students at different levels have. The majority of studies have been conducted with students in primary and secondary education levels, some with junior-high school students and few with university students.

\subsection{Importance of Study Habits Constructs}

Although written tests do not necessarily express the level of understanding of the subject, they are still highly valued as a measure of content assimilation and academic performance. But scores from written examinations on their own do not provide us with a full understanding of why success or failure occurs (e.g., McCall, 1994; Romine \& Crowell, 1981). Hence, it is important to develop constructs that may help education institutions to identify factors affecting performance in test, since how students prepare for exams is determined by study habits. This research focuses on finding how what students do to prepared mid-term and final exams.

One of the purposes of the SSHA (Brown \& Holtzman, 1967) is to identify students whose study habits and attitudes are different from those of students who earn high grades. The reasoning for using study methods as a predictive variable in college is related to the environmental differences between high school and college. Coming to college, students may assume that their study habits and high school success will easily translate to a college setting. However, students soon realize that college is very different from any other environment they have previously experienced (Robinson, 2010).

The study approaches used by students also seem to be situation specific (Beattie, 1997; Biggs, 1988; Eley, 1992). For example, a student studying for a major essay exam is likely to take a deep approach while that same 
student might take a surface approach when studying for a regular multiple-choice exam (Nonis, 2010).

On study skills and habits, the results from different studies vary depending on which specific study habits were measured. Schuman, Walsh, Olson and Etheridge (1985) examined group studying, cramming, degree of note-taking, review of past exams, and going over readings twice, but they concluded that none of these variables have been found to have a direct effect on grades. On the other hand, positive results were found when some combination of study behaviors such as attendance, homework turned in, and use of study guide, prior preparation for the class, participating in class, and coming to class on time were used (Gracia, 2003; Shaftel, 2005; Wooten, 1998 ). Group learning activities can result to an increase in students' deep learning approach, which has been known to improve analytical thinking (Hall, 2004 ). Williams and Worth (2002) conclude that attendance and note-taking predict performance.

Another aspects listed by some scholars regarding what affects academic performance is time spent studying. When considering the relationship between study time and performance, it is not only how much time a student spends studying but also how effectively this time is spent that influences academic performance (Nonis, 2006). According to Stinebrickner and Stinebrickner (2004).

The environment where the program takes place also seems to impact academic performance. Within a country's educational system, the relevant institutions and policies include the ways in which a society finances and manages its schools, how a society assesses student performance, and who is empowered to make basic educational decisions, such as which curricula to follow, which teachers to hire, and what textbooks to purchase (Woesmann, 2001).

Naumann, Bandalos and Gutkin (2003) mention another aspect, first-generation students have unique personal and educational experiences playing roles in their academic performance in college, and they do not typically have the same sources of support as second-generation students do throughout their education.

In their study regarding academic performance of college students, Helsel and Miles (1985) found out that study by elaboration in college differs depending on the level of the students. Seniors students seem to use more study by elaboration $(47 \%)$ and are able to match content with real-life scenarios better than students in lower levels, juniors $41 \%$, sophomore $37 \%$ and freshman $41 \%$. According to Helsel and Miles, study by elaboration in an indicator of academic performance. Hence, it is difficult to precisely define at-risk students because there are so many different factors that could jeopardize students' abilities to be successful in college (Lawson, 2009).

\subsection{Characteristic of High Performing Students}

Students high in metacognitive and self-regulatory abilities are thought to be characterized by active involvement in their own learning process, continuous planning, and carefully monitoring of the task that they are required to complete, their own study behaviors, and the match between task and study behavior (Zimmerman, 1986). In addition, self-regulated learners seek assistance from peers and teachers, possess high self-efficacy and effective time management skills, and are goal directed and self-motivated (Ley, 1998).

Effective studying requires not only that the student possess knowledge of appropriate studying techniques and practices (study skills), but also sustained and deliberate effort (study motivation), self-regulation, ability to concentrate, self-monitoring (study habits), and a sense of responsibility for and value in one's own learning (study attitude) (Diseth, 2003; Entwistle, 1988; Marton, 1976; Schmeck, 1979; Schmeck, 1977; Schmeck, 1982; Watkins, 1983).

Other researches found that high performing students don't put all subjects in one study session, plan when they will study, study at consistent times of the day/week, have specific goals for study sessions, never procrastinate a study session, start with the most difficult subject first, review notes before starting an assignment, avoid being disturb during study sessions, use study groups effectively (to study), review notes, schoolwork and other materials over the weekend and don't cheat in exams (10 Habits of High Effective Students). These habits were observed during classroom observation in the progress of this investigation. Helsel and Miles (1985) mentioned that high performing students are able to make distinctions of sensitive important points during lectures. Beside the above aspects, the researcher lists aspects from field observation of international students that add to the understanding of the issue (see Figure 1).

\subsection{Characteristics of Low Performing Students}

Many circumstances may put a college student at risk of performing low in their academic life, those circumstances include, but are not limited to, socioeconomic status (SES), poor high school grades, lack of social integration, low adaptability to foreign environments, parents who never attended or graduated from college, attending a low performing high school, low self efficacy (Lawson, 2009). In the case of international programs, 
low capacity to develop networks with students from different countries and cultural background may negatively affect academic performance. Some at-risk students come from backgrounds that include a combination of these issues.

In their research on study habits of agronomic students, Helsel and Miles (1985) identified other characteristics of low performing students include: only $10 \%$ of students use instructional objectives before the lectures, most students use instructional materials only previous an exam, only $18 \%$ of students use dictionary to understand concepts, only $20 \%$ of students ask questions to instructors, over estimation of time of concentration, and that only $25 \%$ of students keep pace with reading assignments.

\section{Research Methodology}

4.1 Research Framework

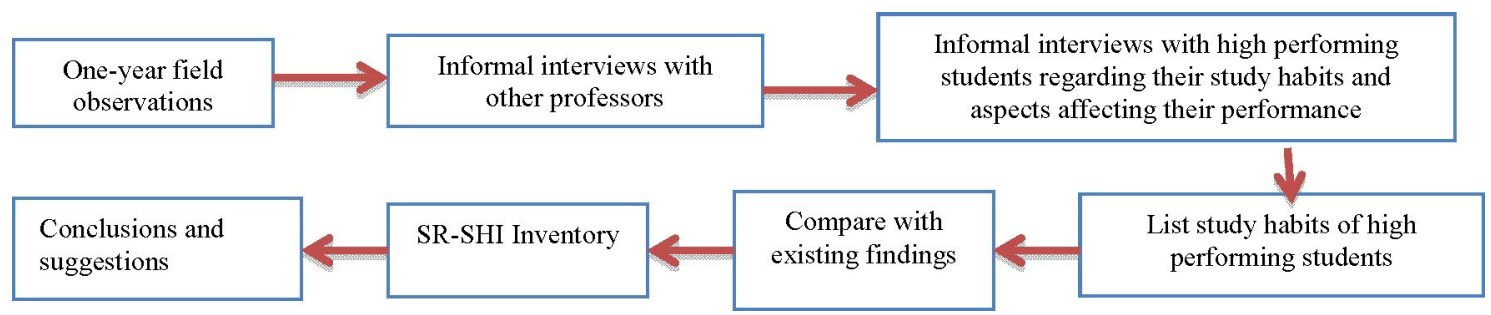

Figure 1. Research framework

\subsection{Hypotheses}

4.2.1 Hypothesis 1: College students from different cultural backgrounds have different study habits, which may negatively or positively affect their academic performance.

4.2.2 Hypothesis 2: There exist study habits of universal value that can be used to identify at-risk students currently enrolled or willing to enroll in international college programs.

4.2.3 Hypothesis 3: There exist study habits of universal value that can be used to develop counseling programs that help low-performing students enrolled in international undergraduate programs to perform better.

\subsection{Purpose}

There is strong evidence regarding the relationship between study habits, skills and attitudes and academic performance (Credé, 2008). Class observations suggest that students' habits inside and outside the classroom may significantly influence their academic performance. With this research, we intend to facilitate the following:

a) A tool to assist education institution in identifying at-risk students before entering the program as well as at-risk existing students so that they can make better decision as to what students to accept and what supporting programs to offer in order to ensure high academic performance.

b) Deeper understanding of how study habits may influence academic performance of students in multicultural undergraduate classrooms.

c) Provide data that may help professors to understand students' strengths and weakness based on their study habits.

d) Provide information that may help to devise study systems that can help low performing students to perform better, and high performing students maintain their interest in the class.

e) Help professors to be better prepared to fulfill their tasks thanks to understanding the factors that may affect students' academic performance.

f) Provide data that may help school counselors to develop and implement better counseling programs aiming at strengthening international student's learning and understanding capabilities.

\subsection{Methodology to Carry on Classroom Observation}

We conducted class observations during spring and autumn 2014, especial attention was given to seating location (back or front of the classroom), class participation and interaction with other students among others. Besides one-to-one and group interview with high-performing students were conducted. Class observations were conducted during morning and afternoon classes, at the Center of International Programs of Donghua University in Shanghai, China. Interviews with high-performing students were conducted at a meeting room in school. 


\subsubsection{Sample}

The most suitable sample strategy for this research is Ramdon Sample Selection, since we were interested in studying the whole population and have within these population I wide diversity of individuals, which help for sampling all stages along the research process.

\subsubsection{Population}

The population for this research is $\mathrm{N}=174$, composed by sophomore students dispersed in four courses: Macroeconomics (27 students), Business Ethics (two sections 23 and 42 students), Management Essentials (42 students) and Organizational Behavior (two sections 25 and 15 students). This population include students enrolled in Business Administration and International Trade and Economics coming from thirty eight different countries including Korea, Indonesia, Brazil, Thailand, Republic of Congo, Russia, Poland, France, Panama, Iran, Iraq, Kazakhstan, Canada, Sweden, Jamaica, Germany, Mexico, Yemen, Venezuela, Zambia, Uganda, Lithuania, Mauritius, United Kingdom, Belgium, USA, Israel, Peru, Colombia, Italy, Nigeria, Morocco, The Netherlands, Chile, Turkey, Angola, Senegal, Namibia and Cote d'lvoire. Some students work and study, and some are business owners or work at their parents' companies. The age range is between 18 and 26 years old. Household income for most students in this sample is over 100,000 USD per year.

\subsubsection{Sample for Class Observation}

We were interested in a sample as diverse as possible in terms of nationalities, age, gender and courses (assuming that some students may preform better in some courses that in others), hence $100 \%$ of the population form the sample for class observations.

\subsubsection{Sample for Interviews with High Performing Students}

However knowledge of low-performing students is important to understand reason for failure, this investigation focuses on finding out study habits of high performing students and on how to encourage low-performing students to adopt those habits. Hence interviews regarding study habits were conducted only with high-performing students. The selection criteria included: first, they must have 80 or higher marks on all subjects already they took before the time this research took place. Second, they should be willing to participate. Third, they should have the time to participate. The professor invited all those students that fit the first criterion. Seven students including one female from Russia, one female from Canada, one male from Japan, two males from Germany, one female from Italy and one female from Brazil form the final sample for this state and provide insights regarding how they arrange their study processes along the whole semester.

\subsection{Fixed Factors Affecting the Research Process}

However teaching methodology and grading systems were not designed specifically for the purpose of this investigation, those are fixed factors that determine the environment and regulations directly affecting the research process, behaviors and habits here studied.

\subsubsection{Teaching Methodology}

a) Combination of lectures, presentation by students, in-class group activities and discussions of relevant case studies and theory.

b) Students were required to read the materials before class.

c) Every effort is made for classroom environments and dynamics to be as close as possible as to those in working environments. One of the key aspects in organizational life is that when a new employee enters the organization he or she is assign a seat as well as a location within the organization and is requested to work with a certain group of people.

We sustain that random or imposed group formation are very important aspects of the training in college, since in real organizational life, new employees have no saying in regard to whom they are willing to work with; so, training adaptation to unfamiliar team members and environments is crucial for undergraduates so that they may quickly integrate to organizational life once they start they professional life.

d) Team presentations and written reports based on one chapter of the textbook. Results are mixed depending on team members. Higher number of students from high-context country developed lower quality of work.

e) Hand in one individual written report related to the subject. Poorly done by low performing students.

f) Students were advised that they would be responsible for their own learning, for which they should read the materials, ask questions and participate in discussions. Low response from low-performing students was observed. Self-controlled learning process is intended to prepare students for independency at work, a much 
desirable qualification employers look for. Independency at work, together with other soft-skills ensures employers a quicker return of investment. High-performing students seems more capable to self-controlled learning processes than low performing students.

g) No midterm exam. Highly welcomed by all the students. The professor in charge of this investigation concentrates in developing the students' capacity to understand the content and its relationship with the real organizational issues, rather than on exact recollection of information from reading materials.

h) Open book final exam. Highly welcomed by all students, but the results were very poor for low and high performing students.

i) Class participation. Students were constantly presented with questions that may contradict the theory. Opinions were given by high performing students, but never by low performing students.

j) Students were advised that the most important goal in class was to understand the applicability of the class content to real-life scenarios, for which they must be able to explain, rather than just repeat, key concepts. Low-performing students perform low in this regard.

\subsubsection{Grading System}

a) Group work $20 \%$ including presentation, written report and any other group assignment.

b) Individual performance $80 \%$ including attendance $(15 \%)$, class participation $(10 \%)$, understanding of the content (20\%), presentation (15\%), other assignments (10\%).

c) Students that perform well on presentations and show to understand the content might be exempted from the final exam.

d) Students who participate in class gain extra points they can use to end the semester with higher grades or cover for missing points in order to pass the subject.

\section{Results and Discussions}

\subsection{Class Observations}

Within the context of this investigation, we observed that most high-performing students are from low-context and individualist countries, while most low-performing students are from high-context and collectivistic countries. Other aspects listed from class observations show that high performing students give opinions based on material and class content, use the expression "I think", ask questions regarding concepts they don't fully understand, are on time to hand in assignments, ask for feedback regarding their assignments, take notes in class, look for the professor after class, seat at the front of the classroom and attend every class. During presentations, students in this category are able to explain the concepts they present in a conversational and analytical manner. When facing low grades on assignments, high performing students look for the professor and utilize facts from the class, reading materials and personal considerations in order to get the marks they believe they deserve.

On the other hand, low performing students remind quite the whole semester unless they are asked questions by the professor, but their participation is normally short and does not refer to reading materials, their participation is repetitive rather than analytical. Besides, low performing students miss at least three classes per semester, are normally late, seat at the back of the classroom, don't take notes in class and never look for the professor after class-hours. During presentations they read from the presentation material rather than explain the concepts they present. When facing low marks they look for the professor and use expressions such as "I worked very hard", "It's not fair" or "It's hard for me to understand the lecture" in order to get their marks they need to pass.

Tables 1 and 2 (below) summarize what high performing students do in class and after class as compared to low performing students. The habits observed on both groups (high- and low-performing students don't seem to be specific to certain countries, but may be affected by cultural factors such as high- and low-context communication patterns as well as individualistic and collectivistic dimensions. The main finding supporting this assumption is that, for this specific environment, course and learning system, most of high performing students are from low-context and mainly from individualistic countries, while most of low-performing students are from high-context mainly collectivistic countries, with some exception that include mainly female students. Age does not seem to be a factor influencing habits either.

\subsection{Interviews}

Results from interviews with the small group of high performing students show habits that are thought especially useful to students enrolled in international programs. Most of the aspects mentioned by the interviewees are also mentioned in previous studies, but perhaps the added value from these interviews is in the multicultural aspects 
mentioned by all high performing students interviewed for this investigation. Such aspects include joining study groups with other high performing students from different countries and meeting socially with students from different countries. These two habits are important since interaction with people from different cultural background allows for wider ideas sharing and make adaptation to foreign environments easier, which in turn lowers the characteristic stress caused by the unknown.

Besides, high performing students study in silence and alone most of the times, study at regular times along the whole semester, take notes in class and while studying, ask questions in class, read the material before lectures and about two weeks before the exam, review notes before the exam, talk about the content with other students. Basically these students prepare for mid and final exams all along the semester, and put an extra effort during the two weeks previous to the exams.

Table 1. Characteristics of high- and low-performing students from classroom observations

\begin{tabular}{l} 
High performing students-Class observations \\
\hline 1. Attend every class \\
2. Are on time for class \\
3. Are on time to hand in assignments \\
4. Follow class instructions and assignments formats \\
5. Take notes in class \\
6. Pay attention in class
\end{tabular}

\section{Proactively give opinions}

9. Their opinions are extensive including "analysis in progress" while speaking.

10. Give personal opinions based on reading material and class content.

11. Look for the professor after class

12. Have a legible handwriting

13. Seat at the front of the classroom

14. Take care of their personal appearance

15. Don't seem to cheat in exams

16. Advance English level

17. Question theoretical approaches based

18. Engage in conversations regarding the topic under study during class discussion sessions

19. Use the expression "I think"

20. Ask questions regarding concepts they don't fully understand

21. Are able to explain the concepts they present in a conversational and analytical manner

22. Ask for feedback regarding their assignments
Low performing students-Class observations

Miss at least three classes per semester

Are normally late for class

Are normally late with assignments

Don't follow neither class instructions nor assignment formats

Don't take notes in class

Engage in conversations unrelated to class content during class

Speak only when the professor asks them a question directly

Their answers are very general and limited to few words without "analysis in progress" while speaking. Their participation is repetitive rather than analytical

Don't give personal opinions

Don't look for the professor after class

Their handwriting is difficult to understand

Seat at the back of the classroom

Don't seem to care for their personal appearance

Cheat in exams

English level is low, especially speaking and listening comprehension

Don't question theory

Remain quite during class discussion sessions

Don't use the expression "I think" or any other indicating that what they say comes from their own thinking process

Don't ask questions

Are not able to explain the concepts they present in a conversational and analytical manner. They normally just read from presentation materials.

Don't ask for feedback regarding their assignments 
23. When facing low marks, look for the professor and utilize facts from the class, reading materials and understanding of the course content in order to get the marks they believe they deserve

24. Engage in conversations regarding the topic under study during class discussion sessions
When facing low marks, look for the professor and utilize expressions such as "I worked hard", "it's not fair" or "it's hard to understand the lecture" in order to get the marks they believe they deserve

Remain quite during class discussion sessions

Note. The content on Table 1 was created from class observation and interview with high performing students.

Table 2. Characteristics of high-performing students from interview

\section{Interview with high performing students}

1. Read supporting materials in English and their own language

2. Interact with students from other countries

3. Attend group study sessions with classmates from other countries

4. Say to feel proud if they get good grades thanks to their effort

5. Study in silence and alone most of the times

6. Study at regular times along the whole semester

7. Read the material before lectures and about two weeks before the exam

8. Review notes before the exam

9. Talk about the content with other students

10. Prepare for mid and final exams all along the semester

11. Put an extra effort during the two weeks previous to the exams

12. Are between 18 and 26 years old

13. Have been previously exposed to China or cross-cultural environments

Note. The content on Table 1 was created from class observation and interview with high performing students.

\subsection{Teaching System and Grading Systems}

An important aspect to mention regarding this investigation is the teaching and grading systems. Based on classroom observations, it becomes apparent that a self-directed study process does not suit students from high-context and collectivistic countries. It also seems that open book exams do not contribute to students' efforts and hence may lower the amount of learning and understanding of the content. Exemption from the final exam seems to be motivating to both high and low performing students to work harder in their individual and group assignments. Extra points didn't influence effort on low performing students but was taken positively by high performing students.

Random group formation seems to be effective in raising students' self-confidence, understanding of the subject among all students, and adaptability of students from low-context countries. Groups formed with students from low-context countries only seem to be more effective than groups forming with students from high-context countries only. Combination of students from low and high context countries seems to be the most effective arrangement to improve performance, but observations at this point deliver mixed results depending on the nationalities included in the group.

\section{The New Construct-Self-Reported Study Habits Inventory for International Students (SR-SHI)}

In order to ensure good performance of students and teachers alike, students enrolled in international programs should be tested regarding their study habits. Knowledge from such tests may help education institutions to plan programs and classroom activities that are more suitable for their corresponding audiences and environments.

Based on previous studies, class observations and interviews with high performing students, I developed the Self-Reported Study Habits Inventory for International Students (SR-SHI) intended to help estimating whether or not a student qualifies as at-risk of having low academic performance. This construct is an adaptation to the Survey of Study Habits and Attitudes (Brown \& Hotzman), the Paragon Student Learning Style Inventory version 
48a, the Index of Learning Styles Questionnaire (Soloman \& Felder) and the Study habits Inventory by F. F. Pozarto (Spanish version).

In order to understand better the importance of this construct, I present a road map showing the line of influence from using this new construct to improving performance (see Figure 2)
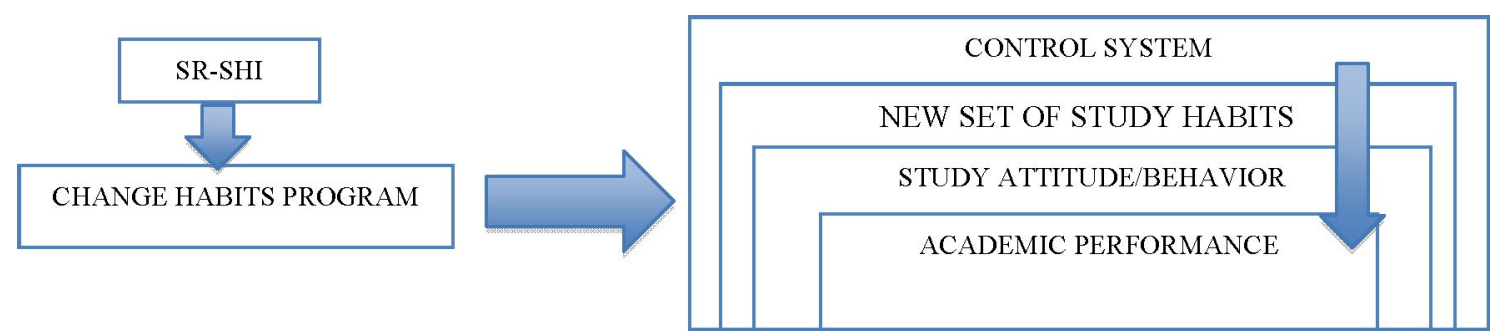

Figure 2. Rooadmap of influence from the utilization of the SR-SHI to enhancing or improving academic performance

Note. The intention of utilizing the SR-SHI is to find out what habits students willing to enroll in international college programs bring with them at the pre-registration stage and determine whether or not they are at risk of low academic performance. With this information, education institutions may devise change study habits programs that, having a control system in place, may lead to change of attitude and behavior, which in turn would lead to new habits and hence benefiting academic performance (See Figure 2 above).

\subsection{Description of the Self-Reported Study Habits Inventory (SR-SHI)}

SR-SHI includes 104 aspects divided into five categories:

1) Habit: what students do.

Ten subcategories including process (12 aspects), body posture ( 2 items), resting period between study sessions of the same and different subjects ( 8 aspects), resting activities between study sessions of the same and different subjects (21 aspects), procrastination ( 3 aspects), effort (4 aspects), personal hygiene (4 aspects), Eating time as related to study sessions (4 aspects).

2) Time: When and or for how long they study and rest (12 categories).

3) Environment: Location (7 aspects), light (2 aspects), sound (4 aspects) and people (5 aspects).

4) Motivation: Why do they study (6 aspects).

5) English level (4 aspects).

\subsection{Justification of the Construct}

Habits: they develop as a response to long-term practices, which in turn derive from our formal and informal education within our specific cultural settings. Habits are observable through behavior, which are influenced by attitude. Once attitude is formed, it directs behavior, which in turn becomes habit after sometime. Since habits and behavior are on the surface, they are more accessible for modification or change.

Study time: it is an important factor to take under consideration when evaluating academic performance since assimilation has much to do with when and for how long the student is exposed to learning material. Habits will influence how much time students spend on self-education activities.

The environment: it includes physical space, light, noise and people; it may affect concentration and hence the quality of a study sessions.

Motivational aspects: crucial in understanding students' performance. The researcher suggests that motivation is instrumental for the student to engage in his or her study process. A motivated student may develop personal interest in learning and hence develop or acquire habits that foster high academic performance.

English level: the level of English is important since it is the main language use in lectures and general communication in the international program where this research was conducted. Low English level will directly affect students' understanding of the subject and hence negatively affect motivation and understanding of the subject, leading to lower academic performance. 


\section{Conclusions}

Study habits seem to be an important determinant of academic performance. However not bounded by country of origin, it seems that some cultural aspects may affect determine habits and hence negatively or positively affect academic performance. It becomes apparent that there exist study habits of universal value that could be taught, monitor and tested along the study process. In order to ensure that all students, from any country, perform well when enrolling in international programs, an examination of their current study habits is important and a useful tool to develop programs that suit multicultural classrooms.

\section{Suggestions}

International schools may fail in delivering high-standards of young professionals because their programs may not be suitable for a community of students from diverse countries. Freshman will always encounter problems to perform in foreign environments because their study habits may not suffice the new requirements, education systems and class dynamics. In that regard, and in order to acquire information to revise or create educational, counseling and change programs that fit international communities, educational institutions offering international programs are advised to make use of constructs such as the SR-SHI presented in this document.

This investigator believes that education should be sustainable in terms of ensuring that students will continue to perform well during their study period and after they graduate, for that to happen, what matters the most is to change attitude. However, in order to achieve this goal, educators and counselors are advised to treat habits first. Figure 3 shows a proposed roadmap from the start of a change program (after utilizing the SR-SHI) to ensuring sustainable performance.

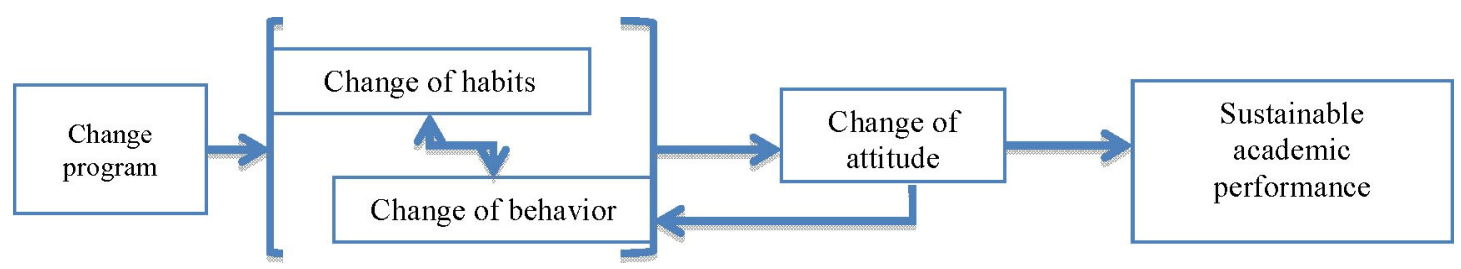

Figure 3. Roadmap to ensuring sustainable academic performance

Note. The change of habits leads to change of behavior and vice versa, which in turn may help to modify or change attitude and so ensuring sustainable academic performance.

\section{Acknowledgements}

Our appreciation to Ms. Yiling Ge, Director of the Center of International Programs of Donghua University for her support and encouragement regarding this research projects. We are also thankful to Natsuaki So, Diana Brigitte Pagenhardt, Luis Jordan and Eleonora Gudetti for their contribution in the process of this investigation.

\section{References}

10 Habits of High Effective Students. (n. d.). Retrieved from http://www.educationcorner.com/habits-ofsuccessful-students.html

Aaron, S. (1999). Correlation of students' characteristics with their learning styles as they begin medical school. Academic Medicine, 74, 260-262. http://dx.doi.org/10.1097/00001888-199903000-00016

Ambrosio, A. L., \& Seguin, C. A. (2001). Assessing Performance-Based Outcomes of Multicultural Lesson Plans: A Component within a Comprehensive Teacher Education Assessment Design. Multicultural Perspectives, 3, 15-22. http://dx.doi.org/10.1207/S15327892MCP0301_4

Baquiran, L. A. (2011). Study Habits and Attitudes of Freshmen Students: Implications for Academic Intervention Programs. Journal of Language Teaching and Research, 2(5), 1116-1121.

Barling, J. C. (1992). Disentangling the relationship between the achievement striving and impatience-irritability dimensions of Type-A behavior, performance, and health. Journal of Organizational Behavior, 13, 360-378. http://dx.doi.org/10.1002/job.4030130405

Beattie, V. C. (1997). Deep and surface learning: A simple or simplistic dichotomy? Accounting Education, 6(1), 1-12. http://dx.doi.org/10.1080/096392897331587 
Beaumont-Walters, Y. A. (2001). An analysis of high school students' performance on five integrated science process skills. Research in Science and Technological Education, 19(2), 133-145. http://dx.doi.org/ 10.1080/02635140120087687

Benjamin, L. T. (2002). Lecturing. In S. F. Davis, \& W. Buskist (Eds.), The teaching of psychology: Essays in honor of Wilbert J. McKeachie and Charles L. Brewer Mahwah (pp. 57-67). NJ: Lawrence Erlbaum Associates, Inc.

Biggs, J. (1988). Assessing Student Approaches to Learning. Australian Psyhologist, 23, 197-206. http://dx.doi.org/10.1080/00050068808255604

Bishop, J. B. (1998). A survey of counseling needs of male and female college students. Journal of College Student Development, 39, 205-210.

Bouffard-Bouchard, T. P. (1991). Influence of self-efficacy on self-regulation and performance among junior and senior high-school age students. International Journal of Behavioral Development, 14, 153-164. http://dx.doi.org/10.1177/016502549101400203

Brown, W. F. (1955). A study-attitudes questionnaire for predicting academic success. J. Ed. Psychol., 46(2), 75-84. http://dx.doi.org/10.1037/h0039970

Brown, W. F. (1972). Student-to-Student Counseling. University of Texas Press.

Credé, M. A. (2008). The Third Pillar Supporting Collegiate Academic Performance. Perspectives on Psychological Science, 3(6), 425-453. http://dx.doi.org/10.1111/j.1745-6924.2008.00089.x

Dahl, D. W. (2011). Does motivation matter? On the relationship between perceived quality of teaching and students' motivational orientations. Managerial Finance, 37(7), 582-609. http://dx.doi.org/10.1108/ 03074351111140243

Davis, B. G. (1993). Tools for teaching. Jossey- Bass.

Diseth, A. A. (2003). Approaches to learning, cognitive style, and motives as predictors of academic achievement. Educational Psychology, 23(2), 195-207. http://dx.doi.org/10.1080/01443410303225

Eley, M. G. (1992). Differential adoption of study approaches within individual students. Higher Education, 23, 231-254. http://dx.doi.org/10.1007/BF00145015

Entwistle, N. A. (1988). Approaches to studying and levels of processing in university students. British Journal of Educational Psychology, 58(3), 258-265. http://dx.doi.org/10.1111/j.2044-8279.1988.tb00901.x

Goss, L. S., \& Bernstein, D. (2005). Teaching psychology: A step by step guide. Mahwah, NJ: Lawrence Erlbaum Associates, Inc.

Gracia, L. A. (2003). A quantitative exploration of student performance on an accounting program of study. Accounting Education: An International Journal, 12(1), 15-32. http://dx.doi.org/10.1080/ 0963928032000049375

Guney, Y. (2009). Exogenous and endogenous factors influencing students' performance in undergraduate accounting modules. Accounting Education: An International Journal, 18(1), 51-73. http://dx.doi.org/ $10.1080 / 09639280701740142$

Haist, S. A. (2000). The Effect of Gender and Age on Medical School Performance: An Important Interaction. Advances in Health Sciences Education, 5(3), 197-205.

Hall, C. (2001). A measure of executive processing skills in college students. College Student Journal, 35, 442-450.

Hall, M. R. (2004). Changing the learning environment to promote deep learning approaches in first year accounting students. Accounting Education, 13(4), 489-505. http://dx.doi.org/10.1080/ 0963928042000306837

Harrell, A. C. (1985). Within-person expectancy theory predictions of accounting students' motivation to achieve academic success. The Accounting Review, 60(4), 724-735.

Hechinger, F. (1982). About education: Developing crucial skills for studying. New York Times, 20.

Lawson, L. A. (2009). The Learning and Study Strategy Inventory as a Predictive Measure of 1st Semester Academic Performance of At-Risk Students. Retrieved from http://www.diginole.lib.fsu.edu/cgi/ viewcontent.cgi?article $=2875 \&$ context $=$ etd 
Ley, K. (1998). Self-regulation behaviors in underprepared (developmental) and regular admission students. Educational Psychology, 23, 42-64. http://dx.doi.org/10.1006/ceps.1997.0956

Loken, E. R. (2004). Online study behavior of 100,000 students preparing for the SAT, ACT, and GRE. Journal of Educational Computing Research, 30, 255-262. http://dx.doi.org/10.2190/AA0M-0CK5-2LCM-B91N

Marton, F. A. (1976). On qualitative differences in learning: Outcome and process. British Journal of Educational Psychology, 58(3), 258-265. http://dx.doi.org/10.1111/j.2044-8279.1976.tb02980.x

Melancon, J. (2002). Reliability, structure, and correlates of Learning and Study Strategies Inventory scores. Educational and Psychological Measurement, 62, 1020-1027. http://dx.doi.org/10.1177/0013164402238088

Miller, D. M. (1972). The relationship of each of six scales of the study attitudes and methods survey (SAMS) to each of two criteria of academic achievement in a community college. Educational and Psychological Measurement, 32, 1107-1110.

Murray, C. (2003). Cognitive, academic, and attitudinal predictors of the grade point average of college students with learning disabilities. Journal of Learning Disabilities, 36, 407-415. http://dx.doi.org/10.1177/ 00222194030360050201

Nonis, S. A. (2010). Performance of College Students: Impact of Study Time and Study Habits. Journal of Education for Business, 85, 229-238. http://dx.doi.org/10.1080/08832320903449550

Nonis, S. P. (2006). Where does the time go? A diary approach to business and marketing students' time use. Journal of Marketing Education, 28(2), 121-134. http://dx.doi.org/10.1177/0273475306288400

Nye, B. K. (2004). How Large are Teacher Effects? Educational Evaluation and Policy Analysis, 26(3), 237-257. http://dx.doi.org/10.3102/01623737026003237

Ogunyemi, A. A. (2011). Academic Self-Efficacy, Study Habit and Attitude in School-Based Assessment, African Assessment. African Journal for the study of Educational Issues, 4.

Paden, N. S. (1997). Reducing procrastination through assignment and course design. Marketing Education Review, 7, 17-25.

Proctor, B. K. (2006). Study skills of normal-achieving and academically college struggling college Students. Journal of College Student Development, 41(1), 37-51. http://dx.doi.org/10.1353/csd.2006.0011

Pychyl, T. M. (2000). Procrastination and the planning fallacy: An examination of the study habits of university students. Journal of Social Behavior and Personality, 15, 135-150.

Rivkin, S. G. (2005). Teachers, Schools, and Academic Achievement. Econometrica, 73(2), 417-458. http://dx.doi.org/10.1111/j.1468-0262.2005.00584.x

Robinson, C. A. (2010). Coaching Students to Academic Success and Engagement on Campus. About Campus, 26-29. http://dx.doi.org/10.1002/abc.20032

Rockoff, J. E. (2004). The impact of individual teachers on student achievement: Evidence from panel data. American Economic Review, 94(2), 247-252. http://dx.doi.org/10.1257/0002828041302244

Sackett, P. R. (2001). High-stakes testing in employment, credentialing and higher education: Prospects in a post-affirmative action world. American Psychologist, 56(4), 304-318. http://dx.doi.org/10.1037/ 0003-066X.56.4.302

Sanoff, A. (2006). What professors and teachers think. Chronicle of Higher Education, 52, B9.

Schmeck, R. R. (1977). Development of a self-report inventory for assessing individual differences in learning processes. Applied Psychological Measurement, 1, 41-43. http://dx.doi.org/10.1177/014662167700100310

Schmeck, R. R. (1979). Academic achievement and individual differences in learning processes. Applied Psychological Measurement, 3, 43-49. http://dx.doi.org/10.1177/014662167900300106

Schmeck, R. R. (1982). Attention to semantic versus phonetic verbal attributes as a function of individual differences in arousal and learning strategy. Contemporary Educational Psychology, 7, 312-319. http://dx.doi.org/10.1016/0361-476X(82)90014-5

Shaftel, J. (2005). The influence of effective teaching in accounting on student attitudes, behavior, and performance. Issues in Accounting Education, 20(3), 231-246. http://dx.doi.org/10.2308/iace.2005.20.3.231

Tanner, K. D. (2013). Structure Matters: Twenty-One Teaching Strategies to Promote Student Engagement and Cultivate Classroom Equity. CEB-Life Science Education, 12, 322-332. http://dx.doi.org/10.1187/ 
cbe.13-06-0115

The official press release for the American freshmen. (2002). Higher Education Research Institute. Los Angeles: University of Carolina Press.

Thompson, M. E. (1976). A New Study Habits Inventory: Description and Utilization. Reading Horizons, 16(3), 143-149.

Wankat, P. C. (2002). The effective, efficient professor: Teaching, scholarship and service. Allyn \& Bacon.

Watkins, D. (1983). Assessing tertiary study processes. Human Learning, 2, 29-37.

Wilson, K. A. (2007). Attention During Lectures: Beyond Ten Minutes. Teaching of Psychology, 34(2), 85-89. http://dx.doi.org/10.1080/00986280701291291

Woesmann, L. (2001). Why Students in Some Countries Do Better? International evidence on the importance of education policy. Education Matters, 1(2), 67-74.

Wrenn, C. C. (1941). Study-habits Inventory. Stanford University Press.

Zeegers, P. (2001). Approaches to learning in science: A longitudinal study. British Journal of Educational Psychology, 71, 115-132. http://dx.doi.org/10.1348/000709901158424

Zimmerman, B. (1986). Development of self-regulated learning: Which are the key subprocesses? Contemporary Educational Psychology, 16, 307-313. http://dx.doi.org/10.1016/0361-476X(86)90027-5

Zimmerman, W. P. (1977). The validity of traditional cognitive measures and of scales of the Study Attitudes and Methods Survey in the prediction of the academic success of Educational Opportunity Program students. Educational and Psychological Measurement, 37, 465-470. http://dx.doi.org/10.1177/ 001316447703700222

\section{Copyrights}

Copyright for this article is retained by the author(s), with first publication rights granted to the journal.

This is an open-access article distributed under the terms and conditions of the Creative Commons Attribution license (http://creativecommons.org/licenses/by/3.0/). 